Chirurgia (2018) 113: 603-610

No. 5, September-October

Copyright@ Celsius

http://dx.doi.org/10.21614/chirurgia.113.5.603

\title{
Diabetes Mellitus as a Risk-factor for Colorectal Cancer Literature Review - Current Situation and Future Perspectives
}

\author{
Alexandra Agache ${ }^{1,2}$, Petronel Mustățea ${ }^{1,2}$, ctavian Mihalache $^{1,2}$, Florin Teodor Bobîrca ${ }^{1,2}$, \\ Dragoș Eugen Georgescu ${ }^{1,2}$, Cristina Mihaela Jauca' ${ }^{1}$ Andra Bîrligea ${ }^{1}$, Horia Doran ${ }^{1,2}$, Traian Pătrașcu ${ }^{1,2}$
}

1"Dr. I. Cantacuzino" Clinical Hospital, Department of General Surgery “I. Juvara”, Bucharest, Romania

2"Carol Davila" University of Medicine and Pharmacy, Bucharest, Romania

Corresponding author:

Dragos Eugen Georgescu, MD

Assistant Professor of General Surgery

"Dr. I. Cantacuzino" Clinical Hospital

5-7 Ion Movila street, district 2

Bucharest, Romania

E-mail: gfdragos@yahoo.com

\section{Rezumat}

Diabetul zaharat ca factor de risc pentru cancerul colorectal Review al literaturii - situatia actuală și perspective de viitor

Cancerul colorectal şi diabetul zaharat constituie o problemă de sănătate publică majoră prin numărul alarmant de cazuri noi, impactul negativ pe care îl au asupra duratei şi calități vieții şi impactul socio-economic, reprezentând cauze de morbiditate şi mortalitate majore. Diabetul zaharat reprezintă boala secolului cu o prevalență globală (vârstă-standardizată) ce aproape s-a dublat din 1980, crescând de la 4,7\% la 8,5\% la populația adultă. Numărul deceselor datorate diabetului zaharat şi complicațiilor acestuia era estimat în 2012 la 3,7 milioane, iar 43\% dintre acestea la pacienți sub 70 de ani. Neoplaziile se clasează pe locul al doilea în rândul principalelor cauze de deces, după bolile cardiovasculare. Cancerul colorectal (CCR) se clasează în ceea ce priveşte incidența pe locul 3 la bărbați şi locul 2 la femei, iar în ceea ce priveşte mortalitatea ocupă locul 4, reprezentând 8,5\% din totalul deceselor prin cancer. $52 \%$ dintre aceste decese se înregistrează în țări mai puțin dezvoltate, ceea ce reflectă o rată a supraviețiirii mult scăzută la nivelul acestor țări. Se aproximează că în fiecare an sunt diagnosticate aproximativ 1.4 milioane de cazuri. Aproximativ 55\% din cazuri apar în țările mai dezvoltate. Screeningul cancerului colorectal se referă la evaluarea periodică a pacienților asimptomatici cu risc de a dezvolta această neoplazie. Cancerul colorectal are o serie de particularități care îl fac ideal pentru screening. Incă de la sfârşitul secolului al XIX lea s-a ridicat suspiciunea că diabetul zaharat tip II ar fi implicat, prin mecanisme direct 
etiologice, în carcinogeneza (sân, endometru, colorectal, pancreas, ficat, limfom nonHodgkin). În momentul de față, există deja un consens în literatura de specialitate privitor la rolul diabetului zaharat tip II ca factor de risc independent in cancerul colorectal. Însă, în pofida existenței a numeroase dovezi experimentale, studii epidemiologice de cohortă, studii caz-control si metaanalize, există necesitatea unor studii prospective care să potențeze rezultatele existente şi să permită o adaptare a screeningului pentru cancerul colorectal la aceşti pacienți.

Cuvinte cheie: diabet zaharat, cancer colorectal, screening

\section{Abstract}

Colorectal cancer and Diabetes Mellitus represent a major public health issue, first, by the number of new cases which are at an alarming rate. Secondly, by the negative effect over the quality of life, socio-economic status and lifespan, representing high morbidity and mortality causes. Diabetes Mellitus is the disease of the century with a global prevalence (standardised-age) which doubled since 1980 , rising from $4,7 \%$ to $8,5 \%$ in adult population. In 2012 , the estimated number of fatalities caused by Diabetes Mellitus and other related complications was at 3,7 million, out of which $43 \%$ were patients under the age of 70 . Neoplasia represents the second cause of death, after cardiovascular disease. The occurrence of Colorectal cancer (CRCA) is rated for men and women at 3rd and 2nd place. However, the rate of mortality from CRCA is in the 4th place, representing 8,5\% out of the total cancer related deaths. $52 \%$ of these cases are recorded in underdeveloped countries, considering their level, this reflects a very low survival rate. Moreover, every year, approximately 1.4 million cases are being diagnosed out of which 55\% appear in overdeveloped countries. Screening for colorectal cancer refers to the periodical evaluation of the asymptomatic patients who are at a risk of developing this type of neoplasia. The colorectal cancer contains a series of particularities which makes it ideal for screening. Since the end of the 19th century there has been a high suspicion that type II diabetes, through direct etiological mechanisms, may play a part in carcinogenesis (breast, endometrium, colorectal, pancreas, liver, non-Hodgkin's lymphoma). At the moment, the relevant published literature presents type II diabetes as an independent risk factor for colorectal cancer. Although, despite experimental proof, many epidemiological studies, case-controlled studies and meta-analysis, there still is the necessity for prospective studies which can intensify the existing results and can allow the colorectal cancer screening to adapt to these patients.

Key words: Diabetes Mellitus, colorectal cancer, screening

\section{Introduction}

\section{Current Situation}

Globally, in 2014, 422 million adults had diabetes, compared to 108 million in 1980. The global prevalence (standardised-age) of diabetes had almost doubled since 1980, rising from 4,7\% to $8,5 \%$ in adult population. This reflects associated risk-factors such as obesity and overweight. In the last decade, diabetes prevalence has increased in under/medium developed countries from over developed ones. Diabetes has caused 1,5 million deaths in 2012. The elevated levels of blood sugar, past the optimal level, have cause an additional 2,2 million deaths by raising the risk of cardiovascular diseases and neoplasia. $43 \%$ out of these 3,7 million deaths occur in patients under the age of 70. The majority of the population is affected by type II diabetes. This was relevant for adults mostly but in the last decade it is becoming more frequent in children as well (1).

Diabetes and the associated complications 
bring a huge financial loss to the people suffering from this disease, to their families, to the health and economic system along with direct medical costs, loss of workforce and labour expenses. While major payments involve hospital and outpatient care, another contributing factor is the rising costs for analogue insulin which has a high prescription rate. Although, there is little evidence that this type of insulin has significant advantages to human insulin which is cheaper (1).

In Romania, the Diabetes Mellitus prevalence rate is over $11 \%$ out of the population ranged from 20-79 years old. According to the data published by the Ministry of Health, in 2011, a number of 796.803 (67\% urban) people registered with diabetes mellitus. Out of which approximately $14,5 \%$ are insulin dependent. On a national level, every year 64.000 people are diagnosed with diabetes mellitus. Separated by age groups, the Romanian population affected by diabetes mellitus is as follows: $3 \%(0-14$ years); $62 \%$ ( $15-64$ years); $35 \%$ (+64 years). It is thought that for each newly diabetes diagnosed patient, there are 1-2 cases of undiagnosed diabetes patients (2).

In September 2012, 802.827 of diabetes cases were registered (67\% urban). During the same period, another 47505 new diabetes cases were registered (approximately 68.000 new cases/year). In 2014, 637.099 diabetes diagnosed people are taken into evidence for oral treatment and 202.271 are treated with insulin (out of which 3.014 are children) (approximately 875.370 people with diagnosed diabetes) (2).

In 2015, the data presented by the Ministry of Health showed a total of 999.192 diabetes cases and the number of people diagnosed during the year of 2015 was 73740 (i.e. 202 cases/day). Moreover, according to the Health Maintenance Organisation (H.M.O) between 2006 and 2016 the settlements for diabetes treatments doubled and the costs increased 6 times.

In the global hierarchy of cancers, from the incidence point of view, the colorectal cancer is the 3rd most common in men (746.00 cases, $10.0 \%$ out of the total), after pulmonary and
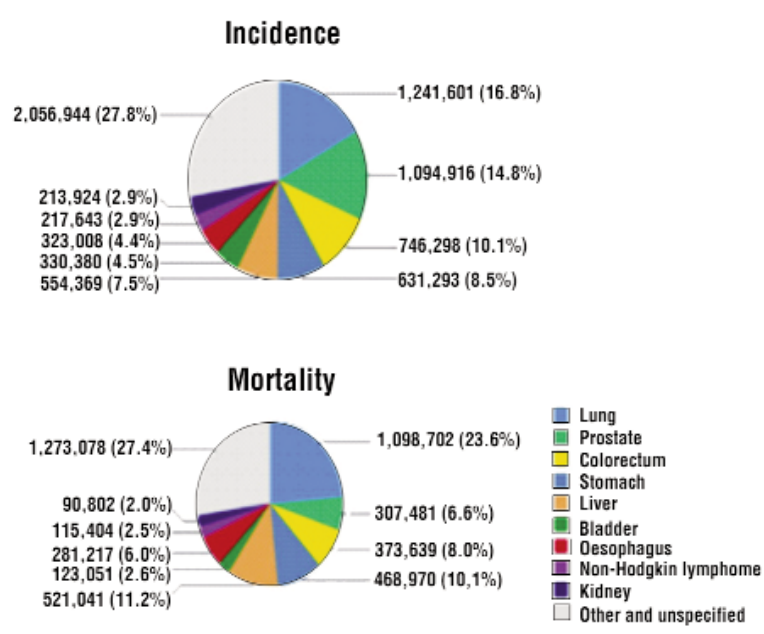

Figure 1. Global incidence and mortality rates for men (3) (adapted from International Agency for Research on Cancer - World Health Organization)

prostate cancer (see Fig. 1), and 2nd most common in women (614.000 cases, 9.2 out of the total), after breast cancer (see Fig. 2). Approximately 1.4 million new cases are being diagnosed every year out of which around 55\% appear in over-developed countries (3).

There is a large geographical variation at a global level and the geographical patterns are very similar for both sexes. The incidence rates vary to 10 folds for both sexes, the highest rates being estimated in Australia / New Zeeland
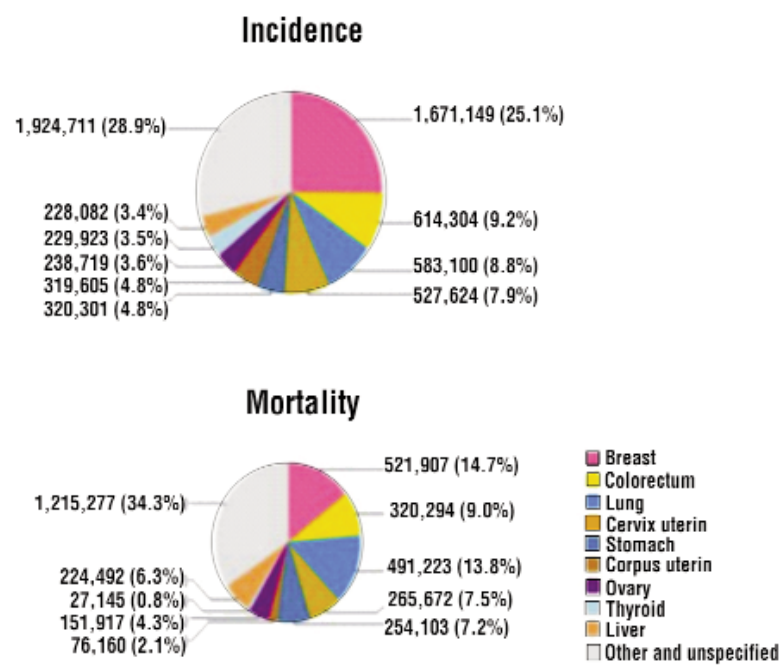

Figure 2. Global incidence and mortality rates for women (3) (adapted from International Agency for Research on Cancer - World Health Organization) 
(approximately 44,8 and 32.2 to 100.000 men and women respectively), and the lowest rates in West Africa (4.5 and 3.8 at 100.000 men and women respectively) (see Fig. 3). Just under 3\% of the cases appear in people aged below 40; the incidence rises rapidly over the age of 45 and doubles with every passing decade (3).

As for the global cancer mortality, the colorectal neoplasia is in the 4th place, after pulmonary cancer, breast cancer and liver cancer with 694.00 deaths representing 8,5\% out of the total cancer related deaths. $52 \%$ of these deaths are happening in under-developed countries, which reflects a much lower rate of survival for these countries. There is less geographical variability regarding the mortality rate (6 fold in men and 4 folds in women), with the highest estimated mortality rate for both sexes in Central and Eastern Europe (20.3 to 100.000 men and 11.7 to 100.000 women), while the lowest mortality rate is recorded in West Africa (3,5 and 3, respectively) (see Fig. 3) (3).

In Romania, the incidence of colorectal cancer is estimated at 13,35/100.000 men and $12,63 / 100.000$ women and its frequency is on the rise (the incidence and mortality rates have doubled in the last 20 years). In 2000, the incidence was estimated at 17,74 per 100.000 and in 2012, an incidence of 38,3 per 100.000 situating Romania as a medium incidence country. Colorectal cancer has become the third cause of death by cancer: 4.150 deaths in 2002 $(19,05$ per 100.000$), 4.860$ deaths in 2006,5675 deaths in 2012 (20,1 per100.000). The men/ women reference is 1,3 . (3-6)

\section{Screening}

Screening for colorectal cancer refers to the periodical evaluation of the asymptomatic patients who are at a risk of developing this neoplasia. The colorectal cancer contains a series of particularities which makes it ideal for screening: it is a frequent disease with a fatal evolution if left untreated in the earlystages; it develops from clearly defined precursor lesions whose excision prevents the outburst of cancer; it progresses slowly in the early stages which are surgically curable to

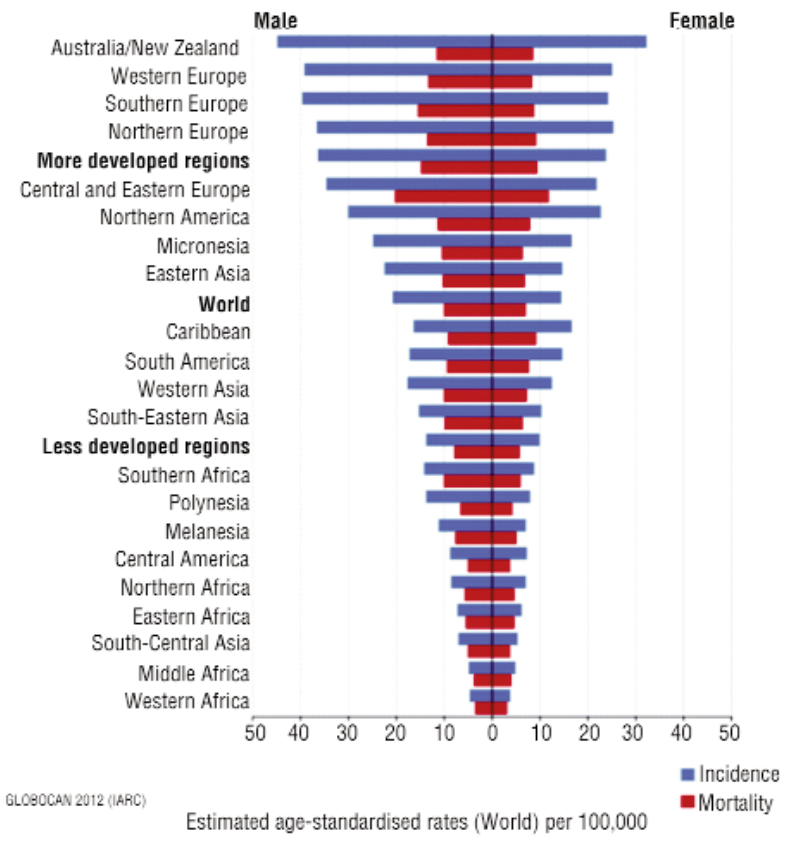

Figure 3. The estimated rates standardised by age per 100.000globally (3)

(adapted from International Agency for Research on Cancer - World Health Organization)

more advanced and metastasised stages; the used screening tests are cost-effective and widely accessible in present times $(7,12,18-27)$.

The screening for colorectal neoplasia is done using the following methods: Testing for occult bleeding in the stool; Recto sigmoidoscopy; Double contrast irrigoscopy (seldom used); Full colonoscopy (gold standard, done whenever one of the other screening methods are positive); Virtual colonoscopy (CT colonography), endoscopic video capsule (easily accepted by patients but not cost-effective); Genetic tests - in case the patient's relatives suffer from specific genetic syndromes.

The American Cancer Society (ACS) has developed an advanced colorectal cancer screening strategy for early detection of colorectal cancer according to the degree of risk for developing this neoplastic disease. It has been settled that this type of screening should be started at the age of 50 for asymptomatic persons. The division of the asymptomatic population in one group risk will be done based on age, personal and family medical history, with the majority $(70-80 \%)$ having a high risk of 
Table 1. The division of asymptomatic persons in risk groups for colorectal cancer (7)

\begin{tabular}{llll}
\hline Factor & $\begin{array}{l}\text { Low-Risk } \\
\mathbf{( 7 0 - 8 0 \% ~ o f ~ c a s e s ) ~}\end{array}$ & $\begin{array}{l}\text { Moderate-Risk } \\
\mathbf{( 1 5 - 2 0 \% )}\end{array}$ & $\begin{array}{l}\text { High-Risk } \\
\mathbf{( 5 - 1 0 \% )}\end{array}$ \\
\hline Age & 50 or over & Any age & Any age \\
\hline Personal medical history & & Adenomatous polyps; colorectal & Chronic inflammatory bowel disease; \\
& & cancer; ovarian and cervical cancer & Crohn's disease, U.H.R.C \\
\hline Family medical history & First-degree relative aged <60,2 or & Family medical history consisting \\
& & more first-degree relatives having & of: familial adenomatous polyposis \\
& & any age with a medical history of: & (FAP); nonpolyposis hereditary \\
& adenomatous polyps or colorectal & colorectal cancer & \\
& & cancer &
\end{tabular}

developing colorectal cancer, and only 5-10\% being considered for the high-risk group (see Table 1) (12, 18-27).

A study published in 2017 on the US population shows that the mortality rate for colorectal cancer has had a progressive decline since 2004 until 2013 of approximately 2,7 percentage per year. Improvement due to colonic polyps detection and excision, early stage CRC detection, more effective adjuvant treatment, and intervention on modifiable risk factors (diet, lifestyle, exercise, smoking). A microsimulation model (MISCAN-Colon) suggests that screening methods can contribute to approximately 53 percent in the reduction rate observed in the colorectal cancer mortality rate. A study of temporal trends in colorectal cancer related to incidence and screening rates in the US reported that approximately 250,000 to 500,000 cases could have been prevented between 1987-2010, along with their early detection (8-12). This decrease was attributed to the recognition of risk factors and, implicitly, the limitation of exposure to them and an effective screening regarding prevention $(13,28)$.

\section{Material and Method}

\section{Diabetes as risk factor for colorectal cancer}

We performed a narrative review of the published evidence in literature. Keywords used were colorectal cancer and diabetes mellitus, risk factors, screening for colorectal cancer and antidiabetic therapies. Relevance of publications was evaluated from titles at the beginning, then from abstracts. Research was carried out on all medical electronic databases (Springer, Pub Med, Medline, Cochrane Library, JNCI, New England Medical Journal, Medscape, BMJ, Journal of Clinical Oncology, Japanese Journal of Clinical Oncology) since 2000 till 2017. Studies were included if they fulfilled specific eligibility criteria (a minimum sample size of 1000 patients; studies based on a variety of geographic regions; studies including in their analysis common risk factors: smoking, obesity, physical exercise, alimentation, studies with statistically significant results, presenting data from multivariable analyses).Concerning exclusion criteria, studies that failed to fulfill the inclusion criteria, or studies in which the outcomes of interest were not reported, were excluded. Studies were excluded if they provided only an estimate of effect with no means to calculate a confidence interval or if the estimates were not adjusted by age.We included 6 studies (3 meta-analyses, 2 cohort studies and one prospective study).

\section{Results}

A meta-analysis published in 2015 which included 15 statistical significant studies (6 case - control; 9 cohort studies) published between January 1966 to July 2005, based on 2,593,935 participants from Europe and US concluded that persons with diabetes type II have a 30 percent higher risk of developing colorectal cancer than non-diabetes persons (summary RR of colorectal cancer incidence $=$ 
$1.30,95 \% \mathrm{CI}=1.20$ to 1.40 ). The association was observed for both genders and for all colorectal cancer localization (31).

A prospective study enrolling a population of 61,320 men and women from Singapore, aged between 45 to 74 years during April 1993 until December 1998, observed either until December 31st 2002 or until diagnosed with CCR concluded that the risk of colorectal cancer has been 50 percent higher on diabetes patients relative to non-diabetes patients (relative risk $(\mathrm{RR})=1.5,95 \%$ confidence interval (CI) $=1.2$ to 1.9). Adjustments based on education levels, IMC, tobacco consumption and alcohol, psychical activity and family history of colorectal cancer did not modify this result. An increased risk has been identified both at male patients $(\mathrm{RR}=1.5,95 \% \mathrm{CI}=1.2$ to 2.1 ) and female patients ( $\mathrm{RR}=1.5,95 \% \mathrm{CI}$ $=1.2$ to 2.1). These estimations have been sim ${ }^{-}$ ilar for colon cancer $(\mathrm{RR}=1.5,95 \% \mathrm{CI}=1.2$ to 2.1) and rectal cancer ( $\mathrm{RR}=1.5,95 \% \mathrm{CI}=1.0$ to 2.1) (35).

A meta-analysis of 14 case - control studies (6) and cohort (8) published between 1997 to 2007 conducted in US and Canada (7 studies), Europe (5 studies) and in Japan (2 studies) following a thorough statistical analysis concludes that patients with diabetes have an associated 38 percent increased risk to develop colon cancer (summary RR 1.38, 95\% CI 1.26$1.51 ; \mathrm{n}=14$ studies) relative to non-diabetic patients; and a 20 percent higher risk of developing rectal cancer (summary RR 1.20, 95\% CI 1.09-1.31; $\mathrm{n}=12$ studies) relative to nondiabetic patients. The association remains after limiting the meta-analysis to studies excluding common risk factors: smoking, obesity, physical exercise. Diabetes was associated with a higher risk for colon cancer both in men (summary RR 1.43, 95\% CI 1.30-1.57; $\mathrm{n}=11$ studies) and women (summary RR 1.35, 95\% CI 1.14-1.53; $\mathrm{n}=10$ studies). For rectal cancer a statistical significant relationship is observed for men (summary RR 1.22, 95\% CI 1.07-1.40; $\mathrm{n}=8$ studies) but not for women(summary RR 1.09, 95\% CI=0.99-1.19; $\mathrm{n}=8$ studies). Six studies included in this meta-analysis show that patients with a longer diabetes mellitus evolution have a higher risk of colorectal cancer. (34)

A cohort study published in 2013 and conducted in Taiwan using a sample of 37,001 diabetic patients and 148,004 control patients selected during January 2004 until December 2005 , monitored for 3 years or until the colorectal cancer diagnosis estimates that the incidence of colorectal cancer is two times higher in diabetes patients relative to control patients (Adjusted hazard ratio=2.1 $(95 \%$ confidence interval, 1.82-2.42). The risk is statistically significant in both male patients (Adjusted hazard ratio $=2.03$ (95\% confidence interval, 1.68-2.47), and female patients (Adjusted hazard ratio $=2.17$ (95\% confidence interval, 1.77-2.67) $(35,36)$.

The medical literature has contributed heavily to the antidiabetic therapy with a numerous amount of studies on it. A cohort retrospective study conducted in UK, using a sample of 62,809 patients with diabetes type II, age higher than 40 years divided in 4 cohorts monotherapy with metformin or sulfonylurea, combined therapy (metformin and sulfonylurea) and therapy based on insulin (Insulin users have been subgrouped in: treatment with insulin glargine, long-acting human insulin, human biphasic insulin and biphasic analogue), concluded that monotherapy with metformin has the lowest risk of colorectal cancer. In comparison: adjusted $\mathrm{HR}=1.08 \quad(95 \%$ CI 0.96-1.21) for metformin and sulfonylurea; 1.36 (95\% CI 1.19-1.54) for sulfonylurea in monotherapy and 1.42 (95\% CI 1.27-1.60) for insulin therapy $(29,30,32,33)$. There are already numerous studies that show that the use of metformin is an independent protective factor against the development of CCR, and that the protective capacity of metformin has been increased in those with long-term therapy, the risk of CCR has been decreasing progressively by increasing the cumulative dose or increasing the intensity of metformin use $(37,38)$. Metformin included to the insulin therapy reduces the progression towards cancer 1.42 (95\% CI 1.27-1.60). Compared with metformin, the insulin therapy increases the risk of colorectal cancer (HR 1.69, 95\% CI 1.23-2.33) $(29,30,32,33)$. 


\section{Discussion}

Findings from this review indicate that individuals with diabetes have an increased relative risk of developing colorectal cancer compared with nondiabetic individuals. The results were consistent for case - control and cohort studies and for studies carried out in the United States, Europe and Asia. The association was observed in both women and men and for all subsites in the colorectum. Our analysis must be interpreted in the context of the limitations of the available data. Most of the studies did not distinguish between type 1 and type 2 diabetes. In addition, because diabetes is an under diagnosed disease, some degree of misclassification of exposure to diabetes is likely to have occurred.

Type 2 diabetes and colorectal cancer share similar risk factors, including physical inactivity and obesity. Thus, the observed increased risk of colorectal cancer associated with a history of diabetes may reflect confounding by these risk factors. However, a positive association between diabetes and colorectal cancer risk remained when the studies were controlled for physical activity and body mass index. Because this analysis included a large number of studies, it could assess the association according to sex and cancer subsite with high precision.

A relationship between diabetes and risk of colorectal cancer is biologically plausible. Type 2 diabetes is characterized by increased insulin concentrations during the early stage of the disease. Hyperinsulinemia or factors related to insulin resistance,such as hyperglycemia or hypertriglyceridemia, have been associated with colorectal carcinogenesis. Insulin can stimulate cell proliferation through a minor pathway that involves the direct activation of the insulin receptor or insulin-like growt factor (IGF)-I receptor and a major pathway that acts through the inhibition of IGF binding proteins (in particular, IGFBP-1 and IGFBP-2), which may result in increased free and bioavailable IGF-I (38). An important role of insulin and IGF-I in colorectal carcinogenesis is supported by in vitro studies, animal models, and epidemiologic studies (38-41). Furthermore, studies reported that chronic insulin therapy was associated with a statistically significant increase in colorectal cancer risk among patients with type 2 diabetes.

\section{Conclusion}

Starting from a comprehensive literature study we wish to raise awarness on a national and international problematic situation taking into account the significant increased number of patients with diabetes and colorectal neoplasms and the improvement in prognosis and survival through screening programs. It is important to acknowledge that type II diabetes is an independent risk factor for the appearance of colorectal neoplasia. Moreover, establishment of adequate screening criteria including this patients is important to improve the quality of life of these patients and the socio-economic impact. Further prospective studies regarding this aspect are needed.

\section{Acknowledgements}

This material is part of the initial review study for the PhD thesis 'Screening for colorectal cancer in patients with type II diabetes' (coordinator prof. dr. T. Patrascu).

\section{Funding Details}

This research did not receive any specific grant from funding agencies in the public, commercial or not-for-profit sectors.

\section{Conflict of Interest}

All author declare that they have no conflict of interest.

\section{Human Rights}

All procedure followed have been performed in accordance with the ethical standards laid down in the 1964 Declaration of Helsinki and its later amendments. 


\section{Author's Contributions}

\section{All authors have equal contributions.}

\section{References}

1. http://www.who.int/diabetes/global-report/en/

2. http://fadr.ro/diabetul-in-romania/

3. http://globocan.iarc.fr/Pages/fact_sheets_cancer.aspx?cancer=colorectal

4. http://eco.iarc.fr/EUCAN/Country.aspx?ISOCountryCd=642.

5. Popescu I. Anexa 11 - Ghid de tratament al carcinoamelor colorectale.

6. Rowe G, Wright G. The Delphi technique as a forecasting tool: issues and analysis. Int J Forecast 1999:4:353-75

7. Levin B. Colorectal Cancer Prevention and Early Detection. In: Willett CG. editor: Cancer of the Lower Gastrointestinal Tract. Atlas of Clinical Oncology. Hamilton, London: B.C. Decker Inc; 2001. p. 45-53.

8. Ferlay J, Autier P, Boniol M, Heanue M, Colombet M, Boyle P. Estimates of the cancer incidence and mortality in Europe in 2006. Ann Oncol. 2007;18(3):581-92.

9. Jemal A, Ward EM, Johnson CJ, Cronin KA, Ma J, Ryerson B, et al. Annual Report to the Nation on the Status of Cancer, 1975-2014, Featuring Survival J Natl Cancer Inst. 2017;109(9).

10. Edwards BK, Ward E, Kohler BA, Eheman C, Zauber AG, Anderson $\mathrm{RN}$, et al. Annual report to the nation on the status of cancer, 19752006, featuring colorectal cancer trends and impact of interventions (risk factors, screening, and treatment) to reduce future rates. Cancer. 2010;116(3):544-73.

11. Yang DX, Gross CP, Soulos PR, Yu JB, Estimating the magnitude of colorectal cancers prevented during the era of screening: 1976 to 2009. Cancer. 2014;120(18):2893-901.

12. Byers T, Levin B, Rothenberger D, Dodd GD, Smith RA. American Cancer Society guidelines for screening and surveillance for early detection of colorectal polyps and cancer: update 1997. CA Cancer J Clin. 1997; 47(3):154-60.

13. Jemal A, Bray F, Center MM, Ferlay J, Ward E, Forman D: Global cancer statistics. CA Cancer J Clin. 2011;61(2):69-90.

14. American Cancer Society: Special section: Colon \& rectum cancer In: Cancer facts \& figures - 1999; Atlanta: 1999. p. 18-23.

15. Gheorghe L, Gheorghe C, Cazacu M. Cancerul colorectal. In: Grigorescu M, editor. Tratat de Gastroenterologie. Bucuresti: Editura Medicala Nationala; 2001. p. 139-173.

16. Feldman M, Friedman LS, Sleisenger MH. Gastrointestinal and Liver Disease Pathology, Diagnosis and Management. Philadelphia London, New York: Saunders. 2002.

17. Mogos D. Diagnosticul cancerului de colon. In: Mogos D, Vasile I, editors. Cancerul de colon. Craiova: Editura Aius; 2000. p. 133-263.

18. Berrino F, De Angelis R, Sant M, Rosso S, Bielska-Lasota M, Coebergh JW, et al. Survival for eight major cancers and all cancers combined for European adults diagnosed in 1995-99: results of EUROCARE-4 study. Lancet Oncol. 2007;8(9):773-83.

19. Barbulescu M. Screeningul în cancerul colorectal. Jurnalul de Chirurgie (lasi). 2007;3(1):19-28.

20. Hewitson P, Glasziou P, Watson E, Towler B, Irwig L. Cochrane systematic review of the effects of the screening for colorectal cancer using the faecal occult blood test, hemoccult: an update. Am J Gastroenterol. 2008;103(6):1541-9.

21. Lang CA, Ransohoff D. Fecal occult blood screening for colorectal cancer. Is mortality reduced by chance selection for screening colonoscopy? JAMA. 1994;271(13):1011-3.
22. Winawer SJ, Fletcher RH, Miller L, Godlee F, Stolar MH, Mulrow $\mathrm{CD}$, et al. Colorectal cancer screening: clinical guidelines and rationale. Gastroenterology. 1997; 112(2):594-642

23. Smith CS, Fenlon HM. Virtual colonoscopy. Best Pract Res Clin Gastroenterol. 2002;16(2):219-36.

24. Eddy DM, Nugent FW, Eddy JF, Coller J, Gilbertsen V, Gottlieb LS, et al. Screening for colorectal cancer in a high-risk population. Results of a mathematical model. Gastroenterology. 1987;92(3): 682-92.

25. Sonnenberg A, Delcò F, Inadomi JM. Cost effectiveness of colonoscopy in screening for colorectal cancer. Ann Intern Med. 2000;133(8): 573-84.

26. Ahlquist DA, Pasha TM. Clinical Aspects of Sporadic Colorectal Cancer. In: Rustgi AK, Crawford JM, editors. Gastrointestinal Cancer. Saunders; 2003. p. 379-404.

27. Gupta AK, Melton LJ III, Petersen GM, Timmons LJ, Vege SS, Harmsen WS et al. Changing trends in the incidence, stage, survival, and screen-detection of colorectal cancer: a population based study. Clin Gastroenterol Hepatol. 2005;3(2):150-8.

28. Edge S, Byrd DR, Compton CC, Fritz AG, Greene F, Trotti A. Colon and Rectum. In: AJCC Cancer Staging Manual 7th Edition. Ed. Springer; 2010. p. 143-165

29. Currie CJ, Poole CD, Gale EA. The influence of glucose-lowering therapies on cancer risk in type 2 diabetes. Diabetologia. 2009; 52(9):1766-77

30. Giovannucci E. Metabolic syndrome, hyperinsulinemia, and colon cancer: a review. Am J Clin Nutr. 2007;86(3):s836-42.

31. Larsson SC, Orsini N, Wolk A. Diabetes mellitus and risk of colorectal cancer: a meta-analysis. J Natl Cancer Inst. 2005;97(22): 1679-87.

32. Sehdev A, Shih YC, Vekhter B, Bissonnette MB, Olopade OI, Polite BN. Metformin for primary colorectal cancer prevention in patients with diabetes: A case-control study in a US population. Cancer. 2015;121(7):1071-8.

33. Yuhara H, Steinmaus C, Cohen SE, Corley DA, Tei Y, Buffler PA. Is diabetes mellitus an independent risk factor for colon cancer and rectal cancer? Am J Gastroenterol. 2011;106(11):1911.

34. Seow A, Yuan JM, Koh WP, Lee HP, Yu MC. Diabetes mellitus and risk of colorectal cancer in the Singapore Chinese Health Study. J Natl Cancer Inst. 2006; 98(2):135-8

35. Wang JY, Chao TT, Lai CC, Wang CY, Wu VC, Wang SM, et al. Risk of colorectal cancer in type 2 diabetic patients: a population-based cohort study. Jpn J Clin Oncol. 2013;43(3):258-63.

36. Chang YT, Tsai HL, Kung YT, Yeh YS, Huang CW, Ma CJ, et al. DoseDependent Relationship Between Metformin and Colorectal Cancer Occurrence Among Patients with Type 2 Diabetes-A Nationwide Cohort Study. Transl Oncol. 2018;11(2):535-541.

37. Fujita $Y$, Inagaki N. Metformin: new preparations and nonglycemic benefits. Curr Diab Rep. 2017 Jan;17(1):5.

38. Giovannucci E. Insulin, insulin-like growth factors and colon cancer: a review of the evidence. J Nutr. 2001;131(11 Suppl): 3109S-20S.

39. Sandhu MS, Dunger DB, Giovannucci EL. Insulin, insulin-like growth factor-I (IGF-I), IGF binding proteins, their biologic interactions, and colorectal cancer. J Natl Cancer Inst. 2002;94(13):972-80.

40. Wu Y, Yakar S, Zhao L, Hennighausen L, LeRoith D. Circulating insulinlike growth factor-I levels regulate colon cancer growth and metastasis. Cancer Res. 2002;62(4):1030-5.

41. Renehan AG, Zwahlen M, Minder C, O'Dwyer ST, Shalet SM, Egger M. Insulin-like growth factor (IGF)-I, IGF binding protein-3, and cancer risk: systematic review and meta-regression analysis. Lancet. 2004;363(9418):1346-53. 